\title{
Hybrid treatment of bullet embolism at the abdominal aortic bifurcation, complicated with thoracoabdominal aorta pseudoaneurysm and common iliac artery occlusion: case report
}

Tratamento híbrido de embolia por projétil de arma de fogo em bifurcação aórtica abdominal complicada com pseudoaneurisma de aorta tóraco-abdominal e oclusão de artéria ilíaca comum: relato de caso

Patrick Bastos Metzger ${ }^{1}$, Rafael Borges Monteiro², Maria Luiza Leite de Medeiros³, Willian Guidini Lima ${ }^{3}$, Vinicius Bertoldi², Fabio Henrique Rossi', Nilo Mitssuru Izukawa', Antônio Massamitsu Kambara

\begin{abstract}
Embolization due to a firearm projectile entering the bloodstream is a rare event that is unlikely to be suspected during initial treatment of trauma patients. We describe and discuss a case of bullet embolism of the abdominal aortic bifurcation, complicated by a pseudoaneurysm of the thoracoabdominal aorta and occlusion of the right common iliac artery, but successfully treated using a combination of endovascular methods and conventional surgery.
\end{abstract}

Keywords: gunshot wounds; embolism; aorta.

\begin{abstract}
Resumo
A embolização por projétil de arma de fogo na circulação sanguínea é rara e de difícil suspeição no atendimento inicial ao trauma. Relatamos e discutimos um caso de embolia em bifurcação aórtica abdominal complicada com pesudoaneurisma de aorta tóraco-abdominal e oclusão de artéria ilíaca comum direita, tratada de forma efetiva pelos métodos endovascular e cirúrgico convencional.
\end{abstract}

Palavras-chave: ferimentos por arma de fogo; embolismo; aorta. 


\section{INTRODUCTION}

Increasing levels of crime and interpersonal violence have driven up the number of patients seen at emergency services because of injuries caused by firearm projectiles over recent decades, to the extent that in Brazil gunshot wounds now have a higher incidence than injuries caused by other agents. ${ }^{1}$

Intravascular embolization by a bullet is a rare event that can cause a range of diverse and severe complications, depending on the site in which the projectile becomes lodged. ${ }^{2,3}$ Whether arterial or venous, it is unlikely that embolization will be diagnosed during initial emergency treatment for trauma and many of these patients are only treated when complications manifest. ${ }^{2-4}$ We describe a case of bullet embolization of the abdominal aorta complicated by a pseudoaneurysm of the thoracoabdominal aorta and occlusion of the right common iliac artery, which was treated using a hybrid approach.

\section{CASE REPORT}

An 18-year-old male patient was admitted to the trauma care department after suffering a gunshot wound to the posterior thoracoabdominal region. There was no evidence of an exit wound and the patient was hemodynamically stable, eupneic and all limb pulses were present. The most notable finding on physical examination was paraplegia of the lower limbs. A chest X-ray located the bullet at the 11th thoracic vertebra (T11), on the right, and found no signs of hemothorax, pneumothorax or pneumoperitoneum. Tomography of the thorax and abdomen only showed a fracture to the body of T11 and the projectile lodged in this topography (Figure 1A). 5 days after hospital admission the patient exhibited coldness and cyanosis of the right lower limb, and femoral and distal pulses were absent. Angiotomography revealed a pseudoaneurysm of the thoracoabdominal aorta, $2 \mathrm{~cm}$ from the celiac trunk, and occlusion of the right common iliac artery (RCIA), showing the bullet located in the abdominal aortic bifurcation topography (Figure 1B, C, D). The decision was therefore taken to attempt endovascular treatment in the hemodynamic suite, using an S-TAG $26 \times 21 \times 100 \mathrm{~mm}$ endoprosthesis (Gore Medical Inc, Flagstaff, Ariz) and a Dryseal ${ }^{\circledR} 18 \mathrm{~F}$ sheath $\left(\right.$ Gore $^{\circledR}$ Medical Inc, Flagstaff, Ariz), and to capture and remove the bullet using a $20 \mathrm{~mm}$ Snare ${ }^{\circledR}$ catheter (Boston ${ }^{\circledR}$ Scientific, USA), and perform angioplasty with a Viabahn ${ }^{\circledR} 9 \times 50 \mathrm{~mm}$ covered stent (Gore Medical Inc, Flagstaff, Ariz) at the level of the RCIA.

The endoprosthesis was successfully placed, covering the pseudoaneurysm neck close to the celiac trunk, thereby resolving it (Figure 2A, B). Abdominal aortography showed that the projectile was lodged at the aortic bifurcation, occluding the RCIA. The bullet was captured using the snare catheter, but because the bullet's diameter had been increased by its impact with the spinal column, it was not possible to remove it via the iliac-femoral segment. In order to deal with critical ischemia of the right lower limb, a covered self-expanding stent was placed into the RCIA, recanalizing the vessel. However, images suggestive of thrombus in the left common iliac artery were observed during a control arteriography. At this point a Smart Control ${ }^{\circledR} 9 \times 60$ mm self-expanding nitinol stent (Cordis ${ }^{\circledR}$ Corporation, Johnson \& Johnson, USA ) was fitted, opening the treated segment to blood flow. However, the bullet migrated back to the RCIA, occluding the covered stent that had been fitted earlier (Figure 2C). The patient was transported to the operating theatre for explorative laparotomy and the bullet was removed from the aortic bifurcation. The stents in the iliac arteries were also removed in view of repeated thromboses, even after an embolectomy catheter had been passed through the affected segments (Figure 3).

The patient was initially kept under observation in the intensive care unit, where he progressed satisfactorily, with lower limb pulses restored and resolution of the critical ischemia of the right lower limb.

\section{DISCUSSION}

Embolization is a rare complication of gunshot wounds, occurring in $0.3 \%$ of penetrating trauma cases. ${ }^{5}$ It occurs when low velocity projectiles enter the bloodstream and migrate through the arterial ( $80 \%$ of cases) or venous systems and become lodged at bifurcations, most commonly the bifurcations of the femoral artery. ${ }^{2,3}$ Thomas Davis was the first to describe foreign body embolization of the bloodstream in 1834, reporting a case of embolization caused by a fragment of wood within the venous circulation. ${ }^{6}$ To date, less than 200 cases have been described in the global medical literature. ${ }^{4}$ Brazilian authors have described three cases of femoral artery embolization treated by conventional surgery over the last 12 years. $^{7}$

Bullet embolization is difficult to diagnose and suspicion should be aroused by three observations, as follows: 1- inconsistency between the number of projectile entry and exit wounds, with no definitive confirmation by radiographic or intraoperative observation of projectiles within body cavities; 2an X-ray showing the bullet in a body cavity distant from the presumed trajectory of the projectile; and; 3- finally, as in the case described here, serial 

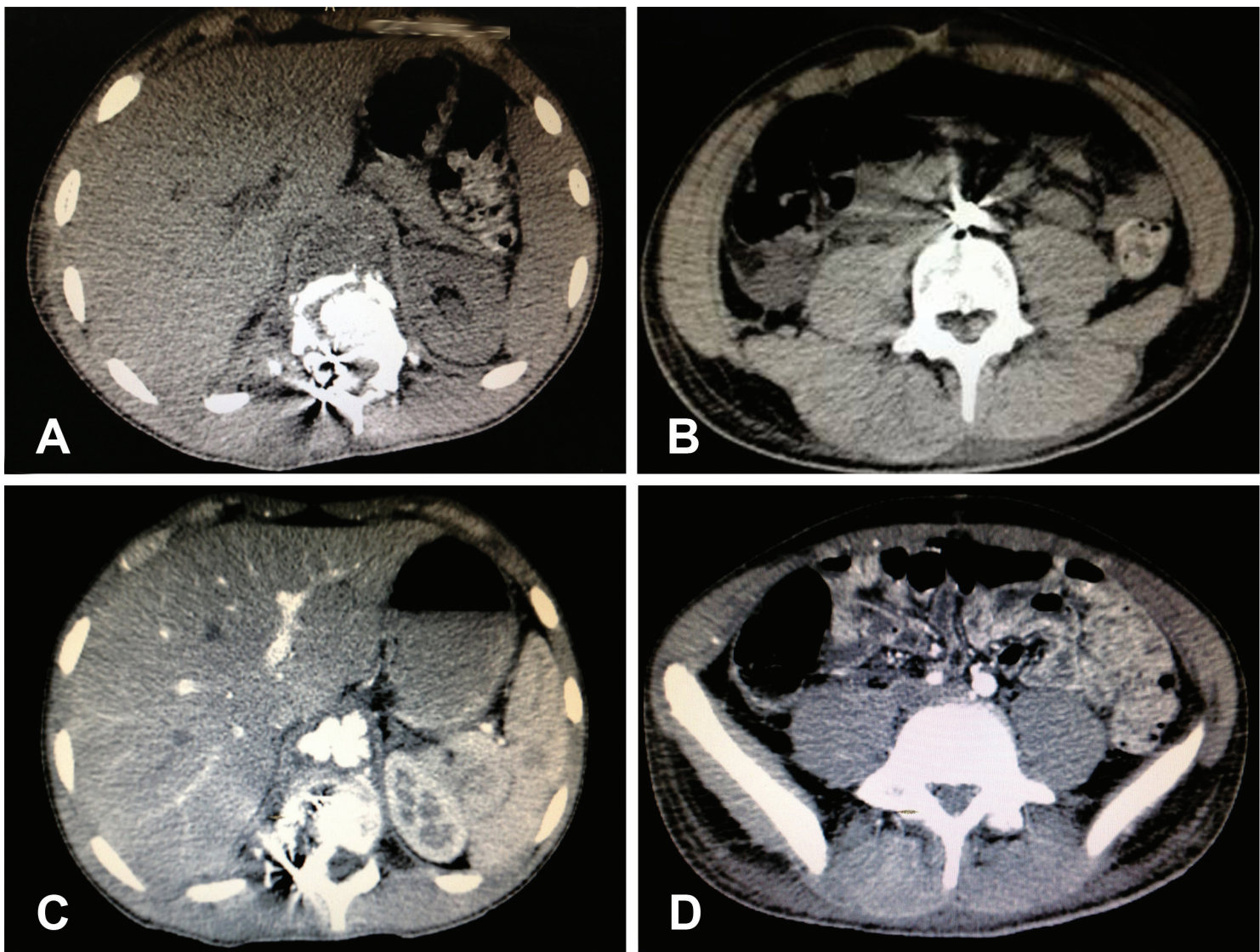

Figure 1. A) Tomography of the upper abdomen showing a projectile at the level of the 11th thoracic vertebra and a comminuted fracture of the vertebral body. B) Tomography of the abdomen 5 days after trauma showing that the bullet had migrated to the level of the fifth lumbar vertebra, in the aortic bifurcation topography. C) Angiotomography 5 days after trauma showing a thoracoabdominal pseudoaneurysm. D) Angiotomography showing occlusion of the right common iliac artery and filling of the external iliac artery.

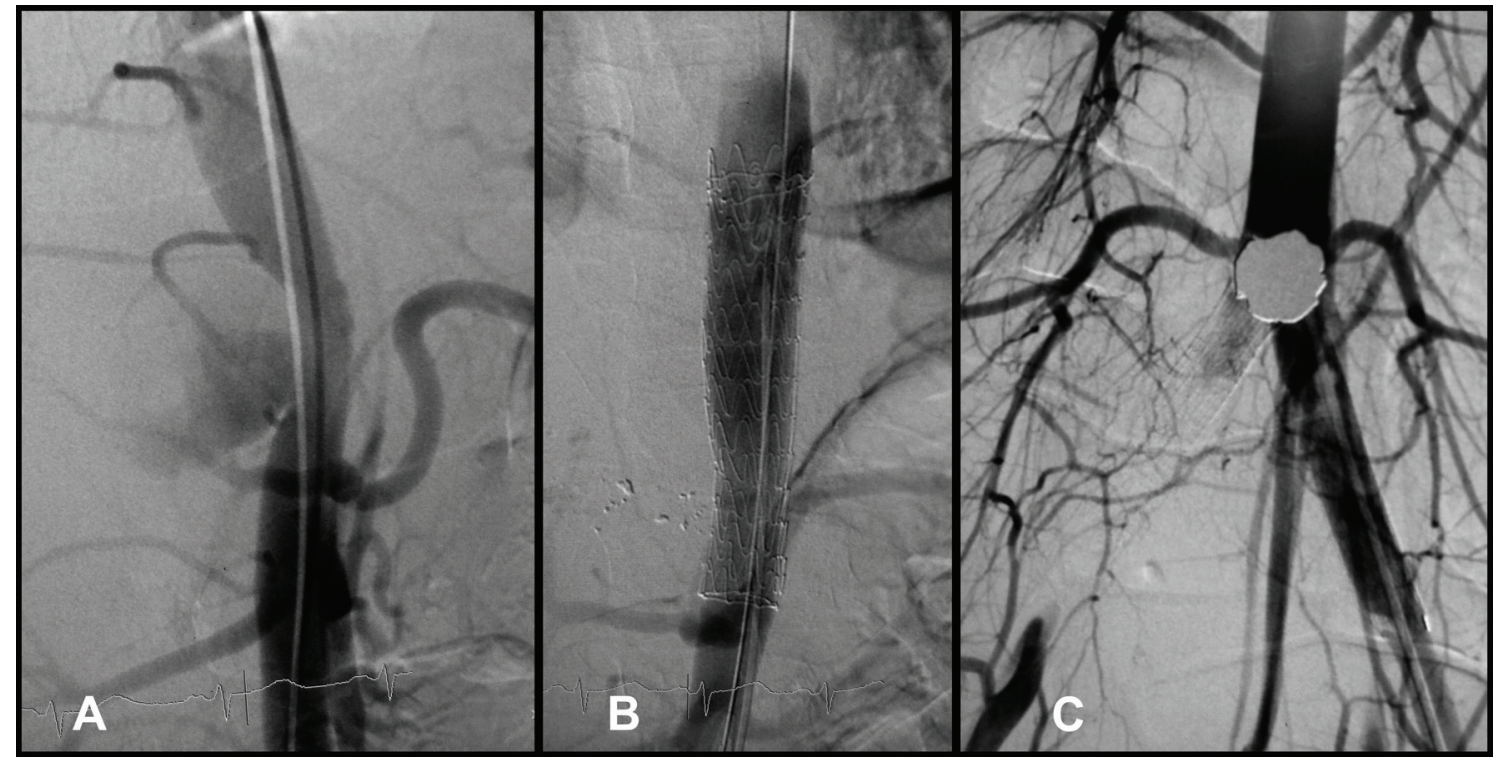

Figure 2. A) Digital subtraction arteriography showing a thoracoabdominal pseudoaneurysm approximately $2 \mathrm{~cm}$ from the celiac trunk. B) Results of endovascular treatment with an S- TAG endoprosthesis, achieving total occlusion of the pseudoaneurysm. C) Aortoiliac arteriography after placement of covered stent on right and self-expanding stent on left. Note the occlusion visible on the right and the negative image, suggestive of thrombus in the stent placed in the left common iliac artery. 



Figure 3. A) Surgical isolation of the aortic bifurcation. B) Aortotomy, removal of bullet and removal of stents. C) Primary arteriography of the abdominal aorta. D) Self-expanding and covered stents. Note the presence of thrombi adhering to the mesh of the self-expanding stent. E) Firearm projectile removed from the aorta. Note, in the detail, the flattened shape of the bullet which prevented its removal via the iliac-femoral segment (front view).

radiological images demonstrating migration of the foreign body. ${ }^{2-4}$

Bullet embolization of the arterial system is often symptomatic because it causes critical ischemia of the limb or organ affected by the occluded vascular segment, and for this reason they are diagnosed earlier than venous emboli, although there is a report in the literature of symptoms emerging 14 months later. ${ }^{8}$ In the case described here, we observed ischemic symptomology in the right lower limb 5 days after the trauma, probably because of migration of the projectile from the thoracoabdominal aorta to the aortoiliac bifurcation, occluding the RCA and causing formation of the thoracoabdominal pseudoaneurysm.

Management of the injuries caused by bullet embolism is dictated by their anatomic location, by the time taken to discover them and by presence or absence of symptomology. There is no doubt that all symptomatic injuries and all arterial damage must be treated. ${ }^{2-4,8,9}$ However, discussions in the literature are ongoing with relation to management of asymptomatic venous injuries, in particular when embolism is the result of bullets lodged in one of two regions: 1- in the pulmonary circulation, without causing ischemia or pulmonary abscesses and bronchial erosion ${ }^{9}$; and 2-in the right ventricle, when bullets smaller than $5 \mathrm{~mm}$ are firmly lodged and there is no evidence of arrhythmia or valve dysfunction. ${ }^{10}$ In such cases, some authors recommend clinical observation. . $^{4-11}$

Intervention options described in the literature range from open surgery techniques, endovascular methods and hybrid approaches. ${ }^{12-15}$ The first description of endovascular removal of a bullet was published in 1980, when a projectile lodged in the right ventricle was captured and removed. ${ }^{16}$ Since then, endovascular methods have become widely 
known and are now the preferred option for treating these conditions. ${ }^{12}$ However, the feasibility of the technique should be considered, bearing in mind that large projectiles or projectiles that are serving to tamponade injuries that are difficult to access using endovascular methods are better managed using conventional surgery or, as in the case described here, using a hybrid approach combining endovascular correction of the traumatic complications of embolism, whether pseudoaneurysms or traumatic aneurysms of the aorta, ${ }^{17,18}$ with subsequent removal of the projectile using open surgery.

\section{REFERENCES}

1. Waiselfisz JJ. Mapa da violência III. Os jovens do Brasil. Brasília: Unesco; 2002. p. 29-120.

2. Keele KL, Gilbert PM, Aquisto TM, Lichtenberg R, Field TC, Lee BK. Bullet Embolus to The Thoracic Aorta with Successful Endovascular Snare retrieval. J Vasc Interv Radiol. 2010 Jan;21(1):157-8. http://dx.doi.org/10.1016/j.jvir.2009.09.007

3. Fernandez-Ranvier GG, Mehta P, Zaid U, Singh K, Barry M, Mahmoud A. Pulmonary artery Bullet embolism- Case report and reviw. Int J Surg Case Rep. 2013;4(5):521-3. http://dx.doi. org/10.1016/j.ijscr.2013.02.017

4. Miller KR, Benns MV, Sciarretta JD, et al. The Evolving Management of Venous Bullet Emboli: A case series and literature review. Injury. 2011 May;42(5):441-6. http://dx.doi.org/10.1016/j. injury.2010.08.006

5. Mattox KL, Beall Jr AC, Ennix CL, DeBakey ME. Intravascular migratory bullets. Am J Surg. 1979;137(February (2)):192-5. http:// dx.doi.org/10.1016/0002-9610(79)90143-0

6. Bining HJ, Artho GP, Vuong PD, Evans DC, Powell T. Venous Bullet embolism to the right ventricle. Br J Radiol. 2007;80(960):e296-8. http://dx.doi.org/10.1259/bjr/64277826

7. Konopka CL, Miletho FN, Jurach A, Aita JF. Bullet embolism: three cases related and literature review. J Bras Med. 2001;80(1-2):41-5.

8. Adegboyega PA, Sustento-Reodica N, Adesokan A. Arterial bullet embolism resulting in delayed vascular insufficiency: a rationale for mandatory extraction. J Trauma. 1996;41(3):539-41. http:// dx.doi.org/10.1097/00005373-199609000-00028

9. Ezberci F, Kargi H. Surgical management of a pulmonary artery missile embolism after an air rifle wound to the liver. South Med J. 1999;92(12):1207-9. http://dx.doi. org/10.1097/00007611-199912000-00015

10. Nagy KK, Massad M, Fildes J, Reyes H. Missile embolization revisited: a rationale or selective management. Am Surg. 1994;60(December (12)):975-9.

11. Kortbeek JB, Clark JA, Carraway RC. Conservative management of a pulmonary artery bullet embolism: case report and review of the literature. J Trauma. 1992;33(6):906-8. http://dx.doi. org/10.1097/00005373-199212000-00020

12. Reil TD, Dorafshar AH, Lane JS, Dong P, Cryer HG, Ahn SS Gunshot wound to the left ventricle with bullet embolization to the descending aorta: combined endovascular and surgical management. J Trauma. 2005;59:1012-1017. http://dx.doi. org/10.1097/01.ta.0000188057.84476.28

13. Von Ristow A, Pallazo JC, Cury JM Fo, et al. Aneurismas Traumáticos da Aorta. J Vasc Bras. 1986;2(1):25-29.

14. Aun R. Ruptura traumática da aorta por traumatismo torácico fechado. J Vasc Bras. 2007;6:5-6. http://dx.doi.org/10.1590/ S1677-54492007000100002
15. Mioto B No, Aun R, Estenssoro AE, Puech-Leão P. Trata- mento das lesões de aorta nos traumatismos torácicos fechados. J Vasc Bras. 2005;4:217-26

16. Hartzler G. Percutaneous transvenous removal of a bullet embolus to the right ventricle. J Thorac Cardiovasc Surg. 1980;80:153-5.

17. Moainie SL, Neschis DG, Gammie JS, et al. Endovascular stenting for traumatic aortic injury: an emerging new standard of care. Ann Thorac Surg. 2008;85:1625-9. http://dx.doi.org/10.1016/j. athoracsur.2008.01.094

18. Brito LCM, Martins JT, Furlani O Jr. Endovascular treatment of thoracic aortic pseudoaneurysm: case report. J Vasc Bras. 2010;9(1):57-60. http://dx.doi.org/10.1590/ S1677-54492010005000002

Correspondence
Patrick Bastos Metzger
CIEV
Av. Doutor Dante Pazzanese, 500 - Vila Mariana
CEP 04012-909- São Paulo (SP), Brasil
E-mail: patrickvascular@gmail.com

Author's information

PBM Médico Cirurgião Vascular e Endovascular do Hospital Municipal do Campo Limpo e do Centro de Intervenções Endovasculares (CIEV) do Instituto Dante Pazzanese de Cardiologia,

São Paulo, SP, Brasil. Título de Cirurgia Vascular e Endovascular pela Sociedade Brasileira de Cirurgia Vascular. Doutorando da Universidade do Estado de São Paulo - USP. RBM Chefe do Serviço de Cirurgia Vascular do Hospital Municipal do Campo Limpo. Cirurgião Vascular e Endovascular do Hospital Municipal do Campo Limpo. Título de Cirurgia Vascular pela Sociedade Brasileira de Cirurgia Vascular

WGL Médico Residente do Serviço de Cirurgia Geral do Hospital Municipal do Campo Limpo. MLLM Chefe da Residência de Cirurgia Geral do Hospital Municipal do Campo Limpo. Título de Cirurgião Geral e Videolaparoscopista pelo Colégio Brasileiro de Cirurgiões

VB Chefe da Diretoria Médica do Hospital Municipal do Campo Limpo. Chefe da Unidade de Terapia Intensiva do Hospital Municipal do Campo Limpo.

FHR Médico Cirurgião Vascular e Endovascular do Centro de Intervenções Endovasculares (CIEV) do Instituto Dante Pazzanese de Cardiologia. Título de Cirurgia Vascular e Endovascular pela Sociedade Brasileira de Cirurgia Vascular.

NMI Doutor, Chefe da Seção Médica de Cirurgia Vascular e do Centro de Intervenções Endovasculares do Instituto Dante Pazzanese de Cardiologia. Membro Titular da Sociedade Brasileira de Cirurgia Vascular. Título de Cirurgia Vascular e Endovascular pela Sociedade Brasileira de Cirurgia Vascular.

AMK Doutor, Chefe da Seção Médica de Radiologia e do Centro de Intervenções Endovasculares do Instituto Dante Pazzanese de Cardiologia, São Paulo, SP, Brasil. Membro Titular do Colégio Brasileiro de Radiologia e Diagnóstico por Imagem (CBR)

Author's contributions Conception and design: PBM, NMI, AMK, RBM Analysis and interpretation: PBM, RBM Data collection: PBM, RBM, MLLM, WGL, FHR Writing the article: PBM

Critical revision of the article: $P B M$ Final approval of the article*: PBM, RBM, MLLM, WGL, VB, FHR, NMI, AMK Statistical analysis: N/A Overall responsibility: PBM, RBM Obtained funding: None

*All authors have read and approved of the final version of the article submitted to J Vasc Bras. 